\title{
Isolation and Identification of Rhizospheric Bacteria in Sugarcane (Saccharum spp. L.) Cultivated on Acrisols and Ferrasols of Dong Nai Province, the Southeast of Vietnam
}

\author{
Hoang Minh Tam ${ }^{1,}$, Cao Ngoc Diep ${ }^{2}$ \\ ${ }^{1}$ Dept. Natural Science Teacher Training, Sai Gon University, HCM City, Vietnam \\ ${ }^{2}$ Dept. Microbiology Biotechnology, Biotechnology R\&D Institute, Can Tho University, Can Tho City, Vietnam
}

Email address:

hoangminhtam18@yahoo.co.uk (H. M. Tam), cndiep@ctu.edu.vn (C. N. Diep)

\section{To cite this article:}

Hoang Minh Tam, Cao Ngoc Diep. Isolation and Identification of Rhizospheric Bacteria in Sugarcane (Saccharum spp. L.) Cultivated on Acrisols and Ferrasols of Dong Nai Province, the Southeast of Vietnam. American Journal of Life Sciences. Vol. 3, No. 2, 2015 , pp. 109-118. doi: 10.11648/j.ajls.20150302.18

\begin{abstract}
Nitrogen-fixing and phosphate-solubilizing bacterial diversity and population dynamics in the Acrisol and Ferrasol rhizosphere of sugarcane grown in Dong Nai province, the eastern of South Vietnam was studied. Soil rhizosphere samples were taken in three districts (sites) of this region. Physical and chemical characteristics of soil samples and total nitrogen-fixing and phosphate-solubilizing bacteria counts were determined by drop plate count method together with $16 \mathrm{~S}$ rRNA gene fragments amplified from DNA using eubacterial universal primers ( $27 \mathrm{~F}$ and $1492 \mathrm{R})$. A total of 31 isolates were isolated on two media (Burk's N-free and NBRIP) and all of them have ability of nitrogen fixation and phosphate solubilization together with IAA biosynthesis. Population of nitrogen-fixing and phosphate-solubilizing bacteria correlated with $\mathrm{N}$ total concentration and organic matter content in soil closely $(\mathrm{P}<0.05)$. The sequences from selected nitrogen-fixing and phosphate-solubilizing bacteria (12 isolates) showed high degrees of similarity to those of the GenBank references strains (between 98\% and 99\%). From 12 isolates, 7 belonged to Bacilli, while 2 were Beta-Proteobacteria, 1 was Acidobacteria and 2 were Bacteroides. Based on Pi value (nucleotide diversity), Bacilli group had the highest theta value and Theta values (persequence) from S of SNP for DNA polymorphism were calculated for each group and Bacilli group had the highest values in comparison to three groups. From these results showed that two strains (Bacillus megaterium B6 (Ferrasols) and Sphingomonas sp. P14 (Acrisols)) revealed promising candidates with multiple beneficial characteristics and they have the potential for application as inoculants adapted to poor soils and sugarcane tree because they are not only famous strains but also are safety strains for agricultural sustainable.
\end{abstract}

Keywords: Acrisols, 16S rRNA Gene Sequence, Ferrasols, Nitrogen-Fixing Bacteria, Phosphate-Solubilizing Bacteria, Rhizosphere, Sugarcane

\section{Introduction}

Sugarcane (Saccharum sp. L.) is grown in more than 120 countries, mainly in Brazil and India [1] and Vietnam with 283,000 ha in which the eastern of South Vietnam occupied 34,395 ha and Dong Nai province had 9,287 ha (27\% among $34,395 \mathrm{ha}$ ) in 2012 [2]. It has been a general practice to apply $250 \mathrm{~kg} \mathrm{~N}$ ha-1 yr-1 or more than in most sugarcane cultivating countries [3] and Vietnamese farmers want to have a high sugarcane yield (over 200 tons/ha), they should apply high quantity of inorganic nitrogen fertilizer (urea)(approx. $200 \mathrm{~kg}$ $\mathrm{N}$ ha-1 $\mathrm{yr}_{-1}, 100 \quad \mathrm{~kg} \quad \mathrm{P}_{2} \mathrm{O}_{5} \quad \mathrm{ha}^{-1}$ (equivalent $400 \quad \mathrm{~kg}$ superphosphate $\left.15 \% \quad \mathrm{P}_{2} \mathrm{O}_{5} \quad \mathrm{ha}_{-1}\right)$ and $150 \quad \mathrm{~kg} \quad \mathrm{~K}_{2} \mathrm{O}$ ha-1 (equivalent $250 \mathrm{~kg} \mathrm{KCl} 60 \% \mathrm{~K}_{2} \mathrm{O}$ ha-1 $\mathrm{yr}-1$ ) [4].

The narrow zone of soil directly surrounding the root systems is referred to as rhizosphere [5], while the term "rhizobacteria" implies a group of rhizosphere bacteria component in colonizing the root environment [6]. Plant growth promoting rhizobacteria are the soil bacteria inhabiting around $t$ or on the root surface and are directly or indirectly involved in promoting plant growth and development via production and secretion of various regulatory chemicals in the vicinity of rhizosphere [7]. Over the last two decades, an increasing number of reports have 
been published showing that plant growth-promoting rhizobacteria (PGPR) are associated with important crops such as rice, wheat, sorghum, sugarcane and maize $[8][9][10][11]$; many plant-associated bacteria are well known for their capacity to promote growth [12]. One of the main focuses of PGPR research is on nitrogen-fixing bacteria (diazotrophs), and this research is aimed at decreasing the use of costly chemical fertilizers that can negatively affect the environment $[13,9]$.

The eastern South Vietnam and the Mekong Delta are two big sugarcane cultivation regions in the South Vietnam; the sugarcane area occupied $12.7 \%$ with 34,395 ha, 66.5 ton/ha and productivity was 2,329,435 tons [2]. The eastern of South Vietnam locates from $105_{0} 49^{\prime \prime}$ to $107 \mathrm{o} 35^{\prime \prime} \mathrm{E}$ and from $10_{\mathrm{o}} 20^{\prime \prime}$ to $12_{\mathrm{o}} 17^{\mathrm{\prime}} \mathrm{N}$, it is one of the two regions of South Vietnam situated in the east of part of South Vietnam, covering 2.34 millions ha, occupied approximately $20.3 \%$ of total of Vietnam area. The soils are mainly red latosols (from origin of volcanic mountain) and acrisols with a $\mathrm{pH}$ range of $4.5-5.0$. They are considered nutrient poor, with an average organic matter of $2 \%$, a total nitrogen range of $0.14-0.19 \%$, and a very low available phosphorus, cation exchange capacity, exchangeable $\mathrm{K}$ and contain more sand in their structure [14].

In order to make sugarcane cultivation sustainable and less dependent on chemical nitrogen fertilizers, it needs to be found the proportion of plant promoting bacteria, which are PGPR. The aims of this study were (i) isolation of rhizospheric bacteria, (ii) studying characteristic such as nitrogen fixation, phosphate solubilization and IAA production, (iii) the genetic diversity of PGPR isolated from soil was evaluated in order to identify an efficient growth promotion strains that can be also improve the growth of sugarcane plant as biofertilizer.

\section{Material and Methods}

\subsection{Soil Sample and Isolation of Bacteria}

The sugarcane plants were sampled at the stage of plant having 6 month-old (July 2013) from the fields of Dinhquan, Trangbom and Vinhcuu districts (Dong Nai province)[map determined the locates which to collect samples were presented in Tam and Diep [15]. Rhizosphere soil around sugarcane plants were collected to moving the soil that adhered to the roots (stem and root of sugarcane plant will be used in further experiment) and they were kept in refrigerator for counting by viable drop plate count [16] and isolation of nitrogen-fixing bacteria in Burk's N free medium [17] and phosphate-solubilizing bacteria in NBRIP medium [18]; cultures were streaked on media to obtain single colonies. To check for phosphate solubilization ability or nitrogen fixation ability, colonies from Burk's $\mathrm{N}$ free medium were streaked to NBRIP medium and colonies from NBRIP medium were also cultivated to Burk's $\mathrm{N}$ free medium in order to select the colonies which developed on two media (or microbes having N2-fixing and phosphate-solubilizing ability).

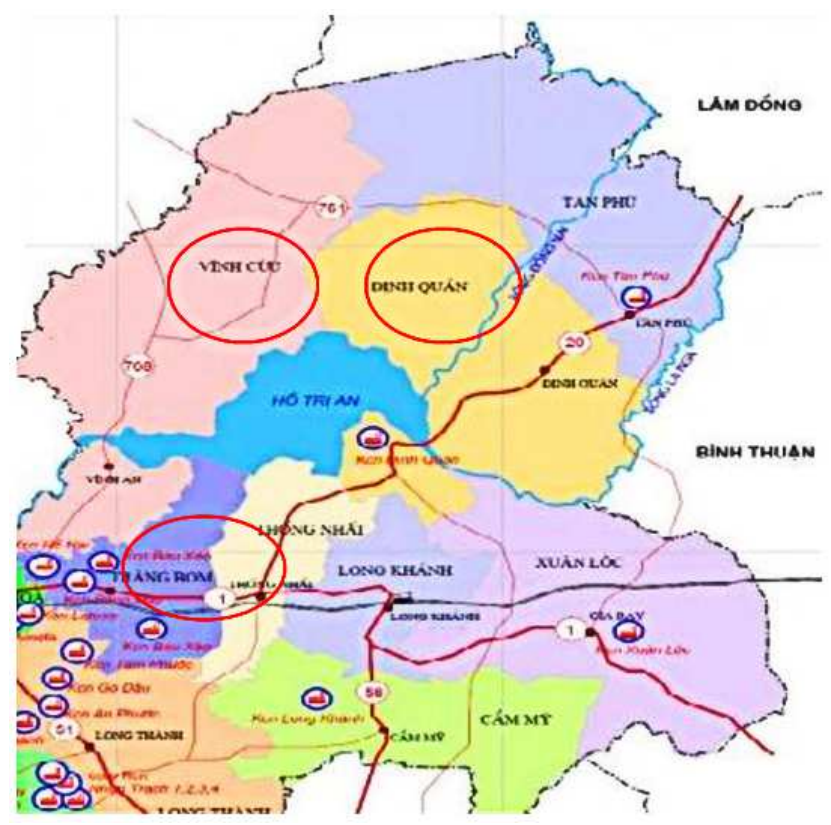

Figure 1. The locations were examined in this study and sugarcane rhizospheric soil were collected at three sites (Dinhquan, Vinhcuu, Trangbom distrcits) of Dongnai pronvince, the eastern of South Vietnam

\subsection{Screening for Biofertilizer Activities}

The ability to fix $\mathrm{N}_{2}$ was tested on Burk's N-free liquid medium incubating at $30 \circ \mathrm{C}$ and the ammonium concentration in medium was measured by Phenol Nitroprusside method after 2, 4, 6 and 8 days inoculation (DAI) and inorganic phosphate solubilization ability was tested on NBRIP liquid medium and they were incubated at $30{ }_{\circ} \mathrm{C}$ and the $\mathrm{P}_{2} \mathrm{O}_{5}$ concentration was measured by ammonium molypdate method. The qualitative detection of indole-3-acetic acid (IAA) production was carried out based on the colorimetric method [19]. Precultures were grown in Burk's N free (100 $\mathrm{mL})$ without tryptophan in $250 \mathrm{~mL}$-flask at $30 \mathrm{oC}$ on a roller at $100 \mathrm{rpm}$ and samples were taken from at 2, 4, 6, and $8 \mathrm{DAI}$, cell free supernatants were mixed 2:1 with Salkowski reagent $\left(0.01 \mathrm{M} \mathrm{FeCl}_{3}\right.$ in $35 \%$ perchloric acid) and incubated in the dark for $20 \mathrm{~min}$ at RT. IAA-containing solutions were indicated by reddish color with an absorption peak at $530 \mathrm{~nm}$ on Thermo Scientific GENESYS 10Uv spectrophotometer.

Besides that, the $\mathrm{pH}$ of rhizosphere soil was measured in a 1:5 soil to water $(\mathrm{w} / \mathrm{v})$ mixture in $20 \mathrm{~min}$ and read on a Jenway $3510 \mathrm{pH}$ meter, $\mathrm{N}$ total were measured using the micro-Kjeldahl digestion method, the colorimetric $P$ determination was based the method of ammonium molypdate method [20] and organic carbon measured by Walkley-Black method [21].

\subsection{S rDNA Gene Amplification and Sequencing}

Bacterial DNA was isolated following published protocols [22]; Amplification of $16 \mathrm{~S}$ rDNA by PCR was carried out using the universal primers $27 \mathrm{~F}$ and $1492 \mathrm{R}$ [23]. The $50 \mu \mathrm{L}$ reactionmixture consisted of $2.5 \mathrm{U}$ Taq Polymerase (Fermentas), $50 \mu \mathrm{M}$ of each deoxynucleotide triphosphates, $500 \mathrm{nM}$ of each primer (Fermentas) and $20 \mathrm{ng}$ DNA. The 
thermocycling profile was carried out with an initial denaturation at $95^{\circ} \mathrm{C}(5 \mathrm{~min})$ followed by 30 cycles of denaturation at $95^{\circ} \mathrm{C}(30 \mathrm{~s})$, annealing at $55^{\circ} \mathrm{C} 55^{\circ} \mathrm{C}(30 \mathrm{~s})$, extension at $72^{\circ} \mathrm{C}(90 \mathrm{~s})$ and a final extension at $72^{\circ} \mathrm{C}(10$ min) in C1000 Thermal Cycler (Bio-Rad).

Aliquots $(10 \mu 1)$ of PCR products were separated and visualized in $1 \%$ agarose gels by using standard electrophoresis procedures. Partial 16S rRNA genes of selected isolates in each group were sequenced by MACROGEN, Republic of Korea (dna.macrogen.com). Finally, 16S rRNA sequence of the isolate was compared with that of other microorganisms by way BLAST (http://www.ncbi.nlm.nih.gov/BLAST/Blast.cgi). In the best isolate(s) (high nitrogen fixation and phosphate solubilization ability) and 12 isolates of 3 sites were chosen to sequence and the results were compared to sequences of GenBank based on partial 16S rRNA sequences to show relationships between PGPR strains [24] and phylogenetic tree were constructed by the neighbor-joining method using the MEGA software version 6.06 based on 1000 bootstraps.

\subsection{PCR Amplification of the nif-H Genes}

PCR amplification was performed to determine the presence of nif-H gene using specific primers described by Poly et al. [25]. Amplification reaction was performed in a total volume of $25 \mu$ l. The reaction mixture contained: $2.5 \mu$ $110 \mathrm{x}$ PCR buffer, $2.5 \mu 1$ of $2 \mathrm{mM}$ each of dATP, dCTP, dTTP and dGTP, $3 \mu 1$ of each forward PolF $\left(5^{\prime \prime}-\right.$ TGCGYCCSAARGCBGACTC-3") and reverse PolR (5"ATSGCCATYTCRCCGGA-3") primer (30 ng), $1 \mu \mathrm{l}$ of template DNA (10 ng) and $0.3 \mu 1$ of (3 U/l) Taq polymerase; final volume was made into $25 \mu 1$ using mili-Q water. The step-up PCR procedure included denaturation at $95 \mathrm{\circ}$ for 3 $\mathrm{min}, 58 \mathrm{oC}$ for $1 \mathrm{~min}$, and $72{ }_{\circ} \mathrm{C}$ for $1 \mathrm{~min}$, followed by 35 cycles of $95 \mathrm{oC}$ for $45 \mathrm{sec}, 58 \mathrm{oC}$ for $45 \mathrm{sec}$, and $72{ }_{\mathrm{o}} \mathrm{C}$ for 1 min, with a final extension at $72{ }_{0} \mathrm{C}$ for $7 \mathrm{~min}$. Amplication products were electrophoreses on $1.5 \%$ agarose gel in $1 \mathrm{X}$ Tris-borate-EDTA (TBE) buffer.

\subsection{SNPs Discovery}

The sequence date from 24 root-associated bacterial isolates were analysed with SeqScape@Software (Applied Biosystem, Foster City, CA, USA). SeqScape is a sequence comparison tool for variant identification, SNP discovery and validation. It considers alignment depth, the base calls in each of the sequences and the associated base quality values Putative SNPs were accepted as true sequence variants if the quality value exceeded 20 . It means a $1 \%$ chance basecall is incorrect.

\subsection{Nucleotide Diversity $(\theta)$}

Nucleotide diversity $(\Theta)$ was calculated by the method described by Halushka et al. [26]

$$
\theta=\frac{\mathrm{K}}{\mathrm{aL}} \mathrm{a}=\sum_{i=2}^{n} 1 /(i-1)
$$

where $\mathrm{K}$ is the number of SNPs identified in an alignment length, $\mathrm{n}$ is alleles and $\mathrm{L}$ is the total length of sequence (bp).

\subsection{Data Analyses}

Relationship between population of nitrogen-fixing and phosphate-solublilizing bacteria and soil $\mathrm{pH}, \mathrm{N}$ total, available $\mathrm{P}$ and organic matter content in acrisols were explored with simple regressions using Exel in Microsoft version 7.0. Data from ammonium, orthophosphate and IAA concentrations in media were analysed in completely randomized design with three replicates and Duncan test at $\mathrm{P}=0.01$ and $\mathrm{P}=0.05$ were used to differentiate between statistically different means using SPSS version 16 .

\section{Results and Discussion}

\section{Soil Characteristics}

Table 1. Soil characteristics and $N_{2}$-fixing and Phosphate-solubilizing bacterial population in acrisols and errasols rhizosphere

\begin{tabular}{llllll}
\hline Soil sample site & Soil pH & N total (\%) & $\begin{array}{l}\text { Avail able } \mathbf{P}_{\mathbf{2}} \mathbf{O}_{\mathbf{5}} \\
(\mathbf{m g} / \mathbf{k} \text { g) }\end{array}$ & $\begin{array}{l}\text { Organ ic matter } \\
(\%)\end{array}$ & $\begin{array}{l}\mathbf{N}_{\mathbf{2}} \text {-fixing bacteria } \\
\text { populatio CFU log g/soil }\end{array}$ \\
\hline Trangbom 1 & 4.58 & 0.12 & 15.6 & 2.12 & $\begin{array}{l}\text { Phosphate -solubilizi } \\
\text { ng bacteria }\end{array}$ \\
Trangbom 2 & 4.62 & 0.14 & 12.7 & 1.51 & 6.126 \\
Trangbom 3 & 5.07 & 0.13 & 11.7 & 1.13 & 6.114 \\
Trangbom 4 & 5.22 & 0.17 & 22.1 & 1.91 & 6.078 \\
Trangbom 5 & 5.49 & 0.15 & 15.3 & 1.62 & 6.178 \\
Vinhcuu 1 & 4.91 & 0.19 & 31.8 & 2.15 & 6.024 \\
Vinhcuu 2 & 5.12 & 0.11 & 16.7 & 1.25 & 5.556 \\
Vinhcuu 3 & 5.58 & 0.14 & 17.3 & 1.68 & 5.531 \\
Dinhquan 1 & 5.39 & 0.04 & 10.6 & 3.25 & 5.381 \\
Dinhquan 2 & 5.49 & 0.03 & 6.6 & 2.25 & 8.107 \\
Dinhquan 3 & 5.66 & 0.05 & 7.1 & 3.01 & 7.958 \\
Dinhquan 4 & 5.37 & 0.07 & 8.3 & 2.78 & 7.326 \\
\hline
\end{tabular}

Three sites in Dong Nai province (in eastern of South Vietnam) have large cultivated sugarcane area (Trangbom, 
Vinhcuu and Dinhquan) and sugarcane has been cultivated on Acrisols (Trangbom and Vinhcuu) and Ferrasols (Dinhquan) showed that characteristic of acrisol is low soil $\mathrm{pH}$ together with low organic matter content while soil $\mathrm{pH}$ and organic matter of ferrasols (Dinhquan) are high; however $\mathrm{N}$ total and available $\mathrm{P}_{2} \mathrm{O}_{5}$ are lower than acrisols (Trangbom and Vinhcuu)(Table 1). Interestingly, nitrogen - fixing bacterial population and phosphate-solubilizing bacterial population in ferrasols were high (almost over one million cells per dry soil gram) but population of phosphate-solubilizing bacteria inacrisols was low? (from one hundred to ten million cells per soil gram).

The results from Table 2 showed that there was no significant linear relationship between population of $\mathrm{N}_{2}$ fixing and phosphate-solubilizing bacteria and soil $\mathrm{pH}$ and both of microbes with organic matter content were a linear relationship significantly at $\mathrm{P}<0.05(\mathrm{y}=1.0853 \mathrm{x}+2.388$, $\mathrm{r}=0.778^{*} ; \mathrm{y}=1.1376 \mathrm{x}+4.0335, \mathrm{r}=0.645^{*}$, respectively) and there was a significant linear relationship between $\mathrm{N}_{2}$ fixing bacteria population with $\mathrm{N}$ total concentration in soil at $\mathrm{P}<0.05\left(\mathrm{y}=15.854 \mathrm{x}+8.2394, \mathrm{r}=0.879^{* *}\right)$ but there was a significant linear relationship between phosphatesolubilizing bacterial population with $\mathrm{N}$ total concentration in soil at $\mathrm{P}<0.05(\mathrm{y}=-13.166 \mathrm{x}+7.841, \mathrm{r}=0.879 * *)$ and there was no difference between population of phosphatesolubilizing bacteria with available phosphorus concentration in soil significantly. These results showed that soil $\mathrm{pH}$ and organic matter content in soil are two important factors affecting to populations of nitrogen-fixing bacteria and phosphate-solubilizing bacteria in soil while $\mathrm{N}$ total in soil correlated with nitrogen-fixing bacterial population rather than phosphate-solubilizing bacteria population in acrisols.

Thirty-one bacterial isolates were isolated from 12 soil samples in two media (Burk's N free and NBRIP medium) (Table 3) with 10, 11 and 10 isolates from Trangbom, Vinhcuu and Dinhquan, respectively and all isolates grew well on both of media (they have nitrogen fixation and phosphate-solubilization ability) and all of them produced indole-3-acetic acid (IAA) in vitro.

Table 2. The relationship between population of $N_{2}$-fixing and phosphatesolubilizing bacteria with $\mathrm{pH}, \mathrm{N}$ total, available phosphorus and organic matter content in soil

\begin{tabular}{lll}
\hline Characteristics & Population (cfu/dry soil gramme) \\
\hline & $\mathbf{N}_{2}$ - fixing bacteria & $\begin{array}{l}\text { Phosphate-solubilizing } \\
\text { bacteria }\end{array}$ \\
\hline soil pH & $\mathrm{r}=0.418(\mathrm{~ns})$ & $\mathrm{r}=0.427(\mathrm{~ns})$ \\
& $\mathrm{y}=1.103 \mathrm{x}+0.724$ & $\mathrm{y}=1.422 \mathrm{x}-1.039$ \\
N total & $\mathrm{r}=0.879^{* *}$ & $\mathrm{r}=0.578^{*}$ \\
concentration (\%) & $\mathrm{y}=15.854 \mathrm{x}+8.239$ & $\mathrm{y}=-13.166 \mathrm{x}+7.841$ \\
Available P & $\mathrm{r}=0.689^{*}$ & $\mathrm{r}=0.419(\mathrm{~ns})$ \\
(mg/kg soil) & $\mathrm{y}=-0.093 \mathrm{x}+7.835$ & $\mathrm{y}=-0.025 \mathrm{x}+6.739$ \\
matter (\%) & $\mathrm{r}=0.778^{* *}$ & $\mathrm{r}=0.645^{*}$ \\
& $\mathrm{y}=1.085 \mathrm{x}+4.238$ & $\mathrm{y}=1.137 \mathrm{x}+4.033$ \\
\hline
\end{tabular}

ns : not significantly different
Table 3. Number of bacterial isolates were isolated from Acrisol from three provinces of the eastern of South Vietnam on two media

\begin{tabular}{llll}
\hline Site & $\begin{array}{l}\text { Total of bacterial } \\
\text { Isolates }\end{array}$ & $\begin{array}{l}\text { Burk's N free } \\
\text { medium }\end{array}$ & $\begin{array}{l}\text { NBRIP } \\
\text { medium }\end{array}$ \\
\hline Trangbom & 10 & 6 & 4 \\
Vinhcuu & 11 & 6 & 5 \\
Dinhquan & 10 & 5 & 5 \\
\hline
\end{tabular}

Table 4. Ammonium $\left(\mathrm{NH}_{4}^{+}\right)$, Available $\mathrm{P}\left(\mathrm{P}_{2} \mathrm{O}_{5}\right)$ and $\mathrm{IAA}$ concentration $(\mathrm{mg} / \mathrm{l})$ of 31 isolates

\begin{tabular}{|c|c|c|c|c|}
\hline \multirow{3}{*}{ Site } & \multirow{3}{*}{$\begin{array}{l}\text { Bacterial } \\
\text { name }\end{array}$} & & Available $\mathbf{P}$ & IAA \\
\hline & & $\left(\mathrm{NH}_{4+}\right)$ & $\left(\mathrm{P}_{2} \mathrm{O}_{5}\right)$ & concentration \\
\hline & & concentration & concentration & $(\mathrm{mg} / \mathrm{L})$ \\
\hline \multirow[t]{10}{*}{ Trangbom } & B1 & 0.057 & 36.13 & 0.144 \\
\hline & B2 & 0.231 & 45.11 & 0.734 \\
\hline & B4 & 0.143 & 41.88 & 0.467 \\
\hline & B16 & 0.649 & 34.01 & 0.574 \\
\hline & B17 & 0.375 & 26.57 & 0.472 \\
\hline & B19 & 0.572 & 27.67 & 0.595 \\
\hline & P1a & 0.231 & 85.20 & 0.525 \\
\hline & $\mathrm{P} 2$ & 0.310 & 116.20 & 0.035 \\
\hline & $\mathrm{P} 4 \mathrm{~b}$ & 0.108 & 122.80 & 0.115 \\
\hline & P19 & 0.161 & 156.70 & 0.533 \\
\hline \multirow[t]{11}{*}{ Vinhcuu } & B9 & 0.985 & 26.98 & 1.031 \\
\hline & B10 & 0.572 & 15.39 & 0.735 \\
\hline & B11 & 0.583 & 37.09 & 0.987 \\
\hline & B12 & 0.407 & 31.27 & 0.343 \\
\hline & B13 & 0.405 & 39.87 & 0.675 \\
\hline & B18 & 0.417 & 29.84 & 0.447 \\
\hline & P8a & 0.110 & 30.63 & 0.268 \\
\hline & P9 & 0.079 & 108.05 & 0.501 \\
\hline & P10 & 0.489 & 103.05 & 1.023 \\
\hline & P14 & 0.579 & 132.90 & 0.913 \\
\hline & P15 & 0.075 & 113.58 & 0.468 \\
\hline \multirow[t]{13}{*}{ Dinhquan } & B3 & 0.293 & 41.88 & 0.850 \\
\hline & B5 & 0.049 & 21.75 & 0.883 \\
\hline & B6 & 0.706 & 17.82 & 0.780 \\
\hline & B7 & 0.044 & 40.58 & 1.036 \\
\hline & B8 & 1.179 & 25.69 & 1.302 \\
\hline & P3 & 0.113 & 173.38 & 0.088 \\
\hline & P5a & 0.097 & 102.28 & 0.381 \\
\hline & P5b & 0.275 & 94.88 & 0.254 \\
\hline & P6 & 0.094 & 118.50 & 0.996 \\
\hline & P7 & 0.156 & 90.40 & 0.176 \\
\hline & control & 0.000 & 0.00 & 0.000 \\
\hline & LSD.01 & 0.053 & 19.68 & 0.168 \\
\hline & C.V & $8.77 \%$ & $16.41 \%$ & $15.88 \%$ \\
\hline
\end{tabular}

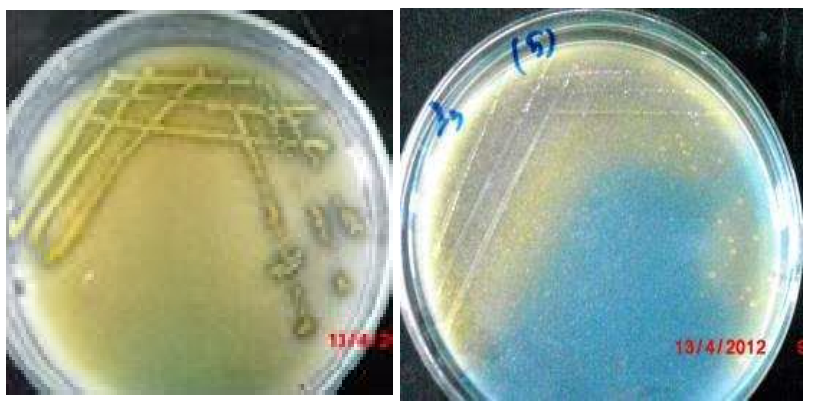

Figure 2. The colonies of several isolates on NBRIP medium (left) with the halos around the colonies and on Burk's $N$ free (right) 


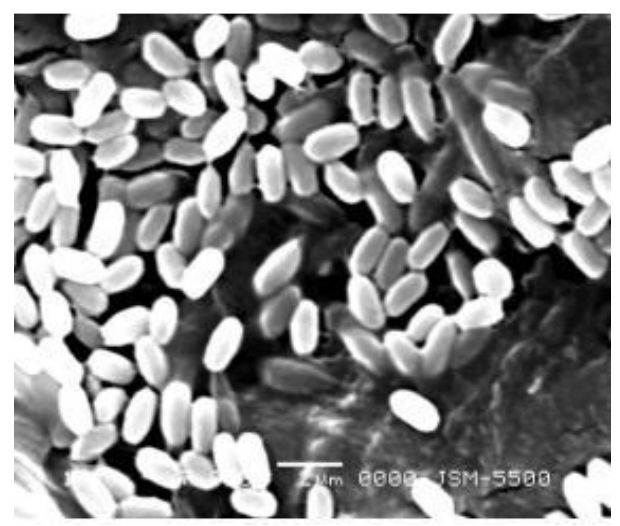

Figure 3. Electron micrograph of cells

The results showed that these bacterial isolates synthesized low ammonium concentration but they solubilized big quantity of phosphorus while the IAA- biosynthesis concentration changed to group of bacterial isolates which isolated from each site (district); IAA concentration varied from 0.035 to $1.032 \mathrm{mg} / \mathrm{L}$. Especially P14 isolate solubilized high amount of phosphorus and synthesized high IAA concentration (Table 4).

Almost their colonies have round-shaped; milky (on Burk's medium) and yellow (on NBRIP medium); entire or lobate margin (Figure 2); diameter size of these colonies varied from 0.2 to $2.5 \mathrm{~mm}$ and all of them are Gram-positive and Gram-negative by Gram stain. Especially phosphatesolubilizing bacteria make a halo around colonies in NBRIP medium as described of Thanh and Diep [27](Figure 2, P14).

The cells were observed by SEM and appeared as short rods and most of them have motility (Figure 3 ).

All 31 isolates have nitrogen fixation (including 14 isolates isolated on NBRIP having nif gene (examined by Pol primers), phosphate solubilization and IAA biosynthesis however 12 isolates having good biofertilizer activity were chosen to study including many isolates from Burk's $\mathrm{N}$ free and NBRIP medium.

The fragment of $1485 \mathrm{bp}$ 16S rRNA were obtained from PCR with $27 \mathrm{~F}$ and $1492 \mathrm{R}$ primers and sequencing. Homology searches of $16 \mathrm{~S}$ rRNA gene sequence of selected strain in GenBank by BLAST revealved that they had similarity to sequences of Bacilli (7/12 isolates), 2 isolates belonged to Betaproteobacteria, 1 was Acidobacteria and 2 were Bacteroides (Figure 4)(Table 5). Especially 7 isolates belonged to Bacilli which isolated on Burk's $\mathrm{N}$ free medium while 5 isolates that isolated on NBRIP medium belonged to three other groups.

Table 5. Phylogenetic affiliation of isolates on the basis of $16 \mathrm{~S} r R N A$ genes sequences by using BLAST programme in the GenBank database based on sequences similarity

\begin{tabular}{|c|c|c|c|}
\hline \multicolumn{2}{|c|}{ Taxonomic group and strain Closest species relative } & \multirow[t]{2}{*}{ Similarity (\%) } & \multirow[t]{2}{*}{ Medium } \\
\hline \multicolumn{2}{|c|}{ Bacilli } & & \\
\hline \multirow[t]{2}{*}{ B2 } & Bacillus subtilis strain PWK31 (KJ620421) & 99 & Burk's $N$ free \\
\hline & Bacillus subtilis strain Bp-1 (KP229430) & 99 & \\
\hline \multirow[t]{2}{*}{ B6 } & Bacillus megaterium strain HNS88 (KF933685) & 99 & Burk's N free \\
\hline & Bacillus aryabhattai isolate PSB59 (HQ242772) & 99 & \\
\hline \multirow[t]{2}{*}{ B8 } & Bacillus megaterium strain HNS68 (KF933665) & 99 & Burk's $N$ free \\
\hline & Bacillus megaterium strain HT-Z56 (KJ526880) & 99 & \\
\hline \multirow[t]{2}{*}{ B9 } & Bacillus subtilis strain YXA1-23 (JF701929) & 99 & Burk's N free \\
\hline & Azospirillum lipoferum, isolate 1:2 (LK3917040 & 99 & \\
\hline \multirow[t]{2}{*}{ B10 } & Bacillus methylotrophicus strain JF29 (KC172004) & 98 & Burk's $N$ free \\
\hline & Geobacillus sp. CRRI-HN-1 (JQ695928) & 98 & \\
\hline \multirow[t]{2}{*}{ B11 } & Bacillus megaterium strain B12 (KF010350) & 99 & Burk's $N$ free \\
\hline & Bacillus horikoshii strain IARI-HHS2-13 (KF054756) & 99 & \\
\hline \multirow[t]{2}{*}{ B17 } & Geobacillus stearothermophilus strain DDKRC4 (JN641292) & 99 & Burk's N free \\
\hline & Bacillus tequilensis strain M60 (JF411297) & 99 & \\
\hline \multicolumn{4}{|c|}{ Acidobacteria } \\
\hline \multirow[t]{2}{*}{ P2 } & Terriglobus roseus strain KBS 112 (DQ660895) & 98 & NBRIP \\
\hline & Terriglobus sp. TAA 43 (AY587228) & 98 & \\
\hline \multicolumn{4}{|c|}{ Betaproteobacteria } \\
\hline \multirow[t]{2}{*}{ P6 } & Burkholderia acidipaludis strain NBRC 101816 (NR_113024) & 99 & NBRIP \\
\hline & Burkholderia sp. D54 (HM467915) & 99 & \\
\hline P8a & $\begin{array}{l}\text { Burkholderia pyrrocinia, strain: Rai } 3 \text { (AB898035) } \\
\text { Burkholderia ambifaria strain } 1835 \text { (KM487704) }\end{array}$ & 99 & NBRIP \\
\hline \multicolumn{4}{|c|}{ Bacteroides } \\
\hline \multirow[t]{2}{*}{ P14 } & Sphingomonas sp. WFR-69 (KC455432) & 98 & NBRIP \\
\hline & Sphingomonas sp. 23R (AY741145) & 98 & \\
\hline \multirow[t]{2}{*}{ P19 } & Sphingomonas sp. EC-K085 (AB264174) & 98 & NBRIP \\
\hline & Novosphingobium subterraneum 23R (AY752914) & 98 & \\
\hline
\end{tabular}




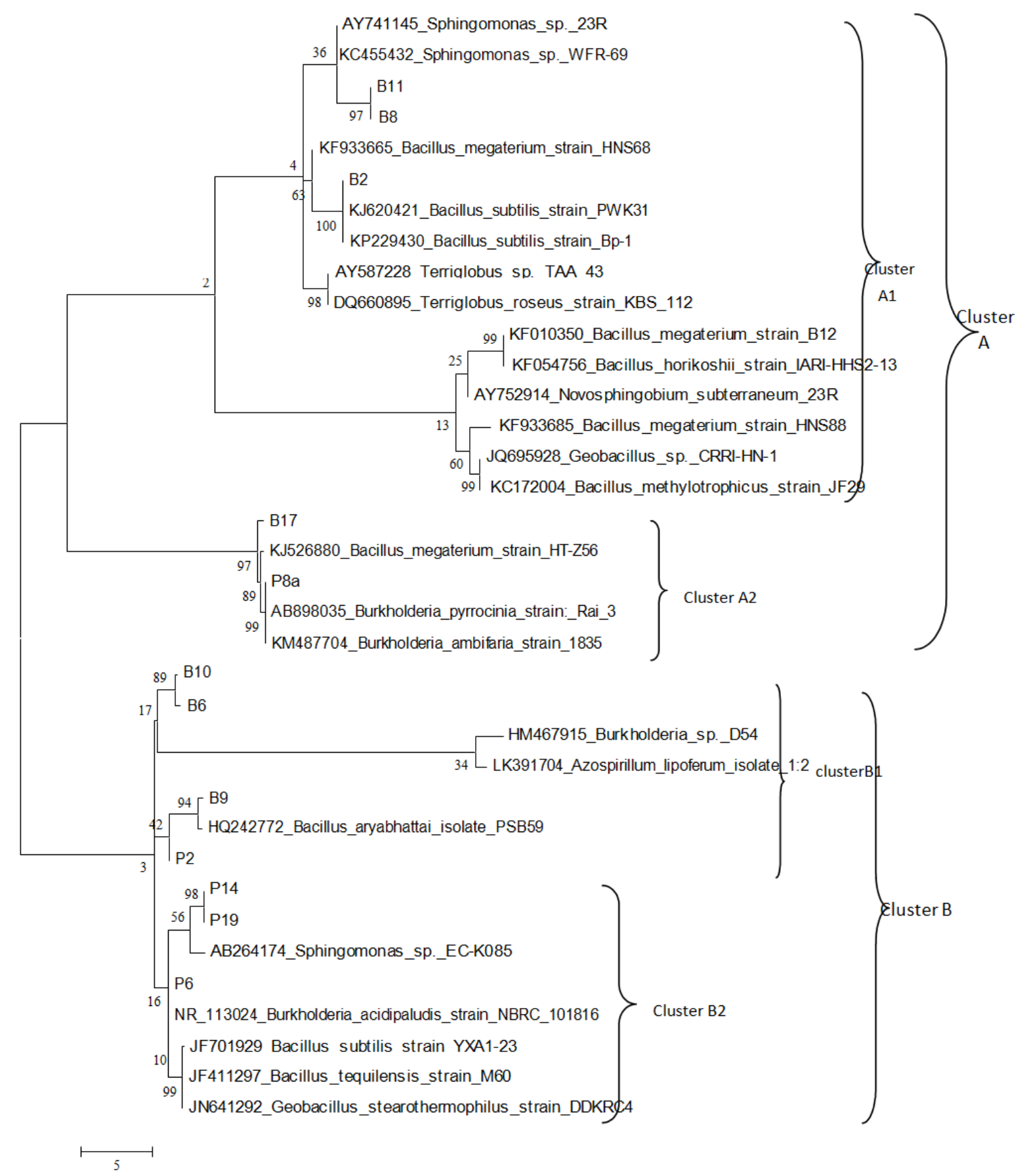

Figure 4. Phylogenetic tree showing the relative position of rhizobacteria (PGPR) by the maximum-likelihood method of complete 165 rRNA sequences. Bootstrap values of 1000 replicates are shown at the nodes of the trees.

A maximum-likelihood tree phylogenetic tree in these isolates showing the two clusters: cluster A with 5 isolates including two small clusters as cluster A1 with 3 isolates (B11, B8 and B2) and cluster A2 with B17 and P8a while cluster $\mathrm{B}$ with 7 isolates arranged in two small clusters, cluster B1 with B10, B6, B9 and P2 and cluster B2 with P14, $\mathrm{P} 19$ and $\mathrm{P} 6$, this result showed that the isolates were isolated from other rhizospheric soils as acrisols or ferrasols, they originated from Vinhcuu site, Dinhquan site or Trangbom site (with distance more than $100 \mathrm{~km}$ far from) but they have the nearest phylogenetic sequences. This result was also demonstrated in the phylogenetic tree with 12 strains (Figure 5). Cluster A divided two small clusters: cluster A1 with cluster A11 with Bacillus megaterium B6, Bacillus methylotrophicus $\mathrm{B} 10$ and Burkholderia acidipaludis P6; cluster A12 with Bacillus subtilis B9 and Terriglobus roseus P2 while cluster A2 with cluster A21 composed of Bacillus megaterium B8 and Bacillus megaterium B11 and cluster A22 with Sphingomonas P14 and Spingomonas P19. Cluster B included with Bacillus subtilis B2, Geobacillus stearothermophilus $\mathrm{B} 17$ and Burkholderia pyrrocinia $\mathrm{P} 8 \mathrm{a}$.

Theta values (per sequence) from $\mathrm{S}$ of SNP for DNA 
polymorphism were calculated for Each group, and Bacilli group had the highest values as comparison with
Acidobacteria, Betaproteobacteria and Bacteroides (Table 6).

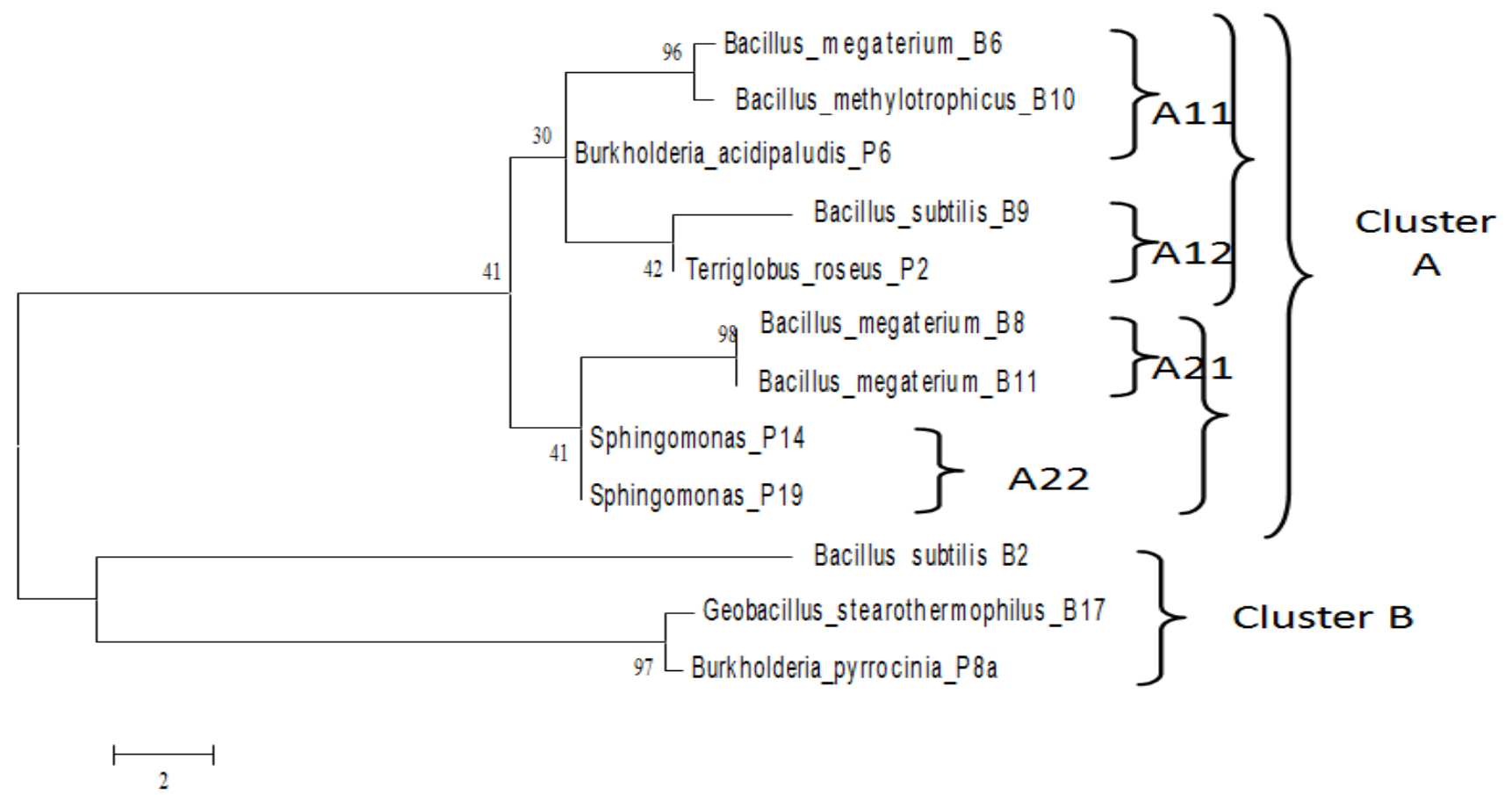

Figure 5. Phylogenetic tree for partial $16 S$ rRNA gene sequences from 12 strains by using primers (27F-1492R) showing relationships between representative strains along with related sequences retrieved from GenBank. The numbers at the nods indicate the levels of bootstrap support (\%) based on MaximumLikelihood analysis of 100-re-sampled datasets. The scale bar indicates the phylogenetic distance corresponding to 5 changes per 100 bases.

Table 6. Genetic diversity of 12 strains

\begin{tabular}{lccc}
\hline & $\begin{array}{l}\text { Nucleotie } \\
\text { diversity }\end{array}$ & $\begin{array}{l}\text { Theta (per site) } \\
\text { from } \text { Eta }\end{array}$ & $\begin{array}{l}\text { Theta (per site) } \\
\text { from } \mathbf{S}(\boldsymbol{\theta})\end{array}$ \\
\hline 12 strains & 0.71432 & $0.88476 \pm 0.126$ & $0.33114 \pm 0.016$ \\
\hline
\end{tabular}

Primers 27F and 1492R

The rhizospheric bacteria has been studied and described as beneficial bacteria with Gram-positive bacteria presented on Burk"s $\mathrm{N}$ free medium and it occupied over $50 \%$ among 12 strains in our result (Figure 6).

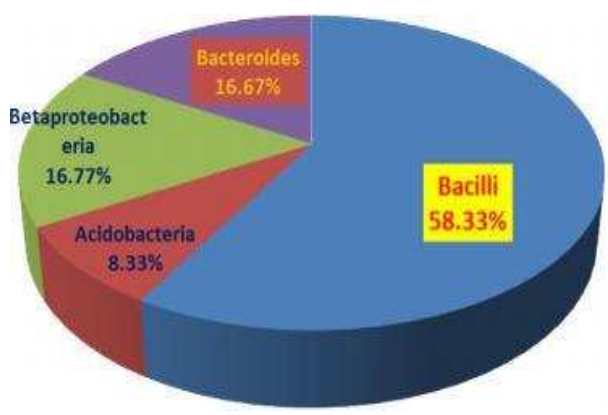

Figure 6. The proportion of group and they distributed in four clusters

Nucleotide polymorphism can be measured by many parameters, such as halotype (genes) diversity, nucleotide diversity, Pi, Theta $(\Theta)$ (per group) etc... In this study, nucleotide diversity was estimated by Theta, the number of segregating sites [28], and its standard deviation (SE). These parameters were estimated by DNA Sequence Polymorphism software version 4.0 [29]. Pi values explained nucleotide diversity of sequences for each gene, the higher values, the more diversity among group. Bacilli group had the highest

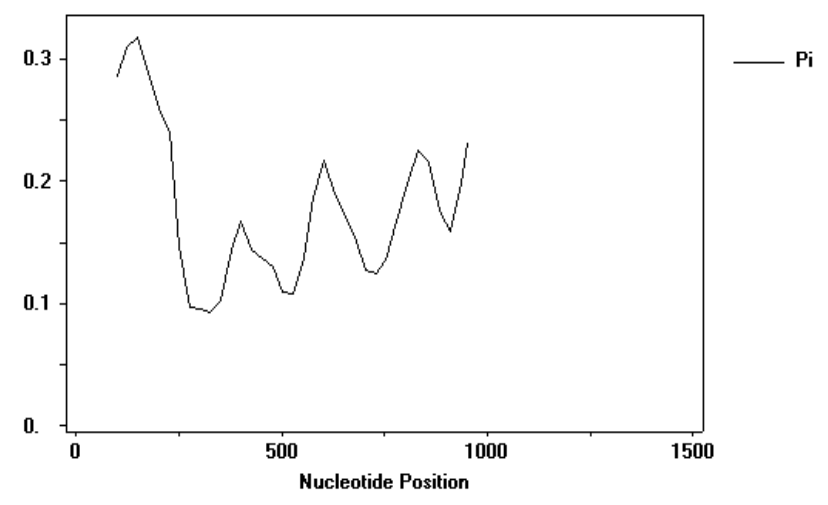

Figure 7. Variation of nucleotide from position 200 to position 400

In 7 Bacilli strains had variation of nucleotide from position 200 to position 400 (Figure 7).

The plant-beneficial rhizobacteria may decrease the global dependence on hazardous agricultural chemicals which destabilize the agro-eco-systems [7]. The rhizobacteria are the dominant deriving forces in recycling the soil nutrients and consequently, they are crucial for soil fertility [30]. The plant growth promoting rhizobacteria (PGPR), are characterized by the following inherent distinctiveness: (i) they must be proficient to colonize the root surface (ii) they must survive, multiply and compete with other microbiota, at 
least for the time needed to express their plant growth promotion/protection activities, and (iii) they must promote plant growth [31]. Many plant-associated bacteria are well known for their capacity to promote [32]. Analyses of $16 \mathrm{~S}$ rRNA gene sequences revealed the presence of plant growth promoting (PGPR) species of Burkholeria, Pantoea, Pseudomonas and Microbacterium in sugarcane endophytic bacterial communities [33,34]. Furthermore, new species of aerobic endospore forming bacteria (AEFB) have been isolated from sugarcane internal tissues and rhizosphere [35][36][37].

'Bacilli' AEFB are a diverse group with wide distribution in agricultural soils that contribute both directly and indirectly to plant development [38]. Numerous Bacillus and related genera with plant growth promoting (PGP) activities have been isolated from soybean, corn, sorghum and wheat rhizospheres [39][40][41]. Eichorst et al. [42] discovered a new genus Terriglobus with Terriglobus roseus, belonged to phylum Acidobacteria, its colonies were approximately 1 $\mathrm{mm}$ in diameter and either white or pink, the latter due to a carotenoid(s) that was synthesized under $20 \%$ instead of $2 \%$ oxygen, especially its potential widespread distribution in soil. Genus Sphingomonas discovered and presented the physiology and ecology by White et al. [43] and Ali et al. [44] reported genus Sphingomonas has a ability of nitrogen fixation, phosphate and potassium solubilization and Sphingomonas together with Burkholderia, Bacillus, Pseudomonas have been used biofertilizing microbes. Recently Bumunang and Babalota [45] examined the rhizobacteria from field grown GM maize in South Africa as follows species of Pseudomonas, Aeromonas, Sphingomonas, Burkholderia, Bacillus, Stenotrophomonas, Achromobacter, Ewingella, they have catalase activity, ammonia production, IAA production, phosphate solubilisation and antifungal activity. Our results also found the rhizospheric bacteria in acrisols and ferrasols with species of bacilli, betaproteobacteria as Burkholderia, Acidobacteria and Sphingomonas.

\section{Conclusion}

From 13 soil samples of acrisols and ferrasols of sugarcane regions in three districts (sites) of Dong Nai province, the eastern of South Vietnam, 31 isolates were isolated on two media (Burk's N free and NBRIP) and they were identified as rhizospheric bacteria and 12 isolates having good plant growth promotion were chosen to analyse their relationship. These isolates were identified as Bacilli (more than 50\%), Acidobacteria, Burkholderia, Sphingomonas on both soils (acrisols and ferrasols). Among them, there are two strains will be suggested to produce for sugarcane cultivation on acrisols and ferrasols in the future.

\section{Acknowledgements}

The authors thank the helpness of Microbiology BSc. Students and technicians in the Environment Microbiology
Laboratory, Biotechnology R\&D Institute, Can Tho University, Vietnam; especially Associate Professor Dr. TRUONG TRONG NGON, Head of Molecular Biotechnology Department, Biotechnology R\&D Institute, Can Tho University, Vietnam for analysing molecular data.

\section{References}

[1] J.L. Baldani, V.M. Reis, V.L.D. Baldani and J. Dobereiner, "A brief story of nitrogen fixation in sugarcane - reasons for success in Brasil,” Funct. Plant. Biol., vol.29, pp.417-423, 2002.

[2] L.H.A. Thi, "Report of Sugarcane production in 2012 (Vietnamese)," Department of Agriculture and Rural Development, Vietnam 2013.

[3] N. Tejera, C. Lluch, M.V. Martinez-Toledo and J. GonzalezLopez,"Isolation and characterization of Azotobacter and Azospirillum strains from the sugarcane rhizosphere," Plant Soil., vol. 270, pp:223-232, 2005.

[4] N.D.Quang, C.A.Duong, T.T.M.Dung and D.C. Thong, "Process of Sugarcane Cultivation in the eastern of South Vietnam (Vietnamese)," Department of Agriculture and Rural Development, Vietnam, 2010.

[5] T.S. Walker, H.P. Bais, E. Grotewold, and V.M. Vivanco, "Root exudation and rhizosphere biology," Plant Physiol., vol.132, pp. 44-51, 2003.

[6] J.W. Kloepper, W. Mahafee, J.A. McInroy and P.A. Beckman, "Comparative analysis of methods for recovering plant growth-promoting rhizobacteria from roots," Can. J. Microbiol., vol. 39, pp.953-957, 1991.

[7] M. Ahemad and M. Kilbert, "Mechanisms and applications of plant growth Promoting rhizobacteria: Current perspective,". Journal of King Saud University - Science. http://dx.doi.org/10.1016/j.jksus. 2013.05.001.

[8] Y. Okon,"PGPR-technology cases of application and futureprospects. In: A. Hartmann, M. Schmid, W. Wenzel, Ph. Hisinger (eds) Rhizosphere 2004 - Perspective and Chalenges," A. Tribute to Lorenz Hiltner, GSF, Neurenberg, pp. 273-274, 2005.

[9] E.K. James, "Nitrogen fixation in endophytic and associative symbiosis," Field Crops Res., vol. 65, pp. 197-209, 2000.

[10] M. Andrews, E.K. James, S.P. Cumming, A.A. Zavalin, L.V. Vinogradova, and B.A. McKenzie,"Use of nitrogen-fixing bacteria inoculants as a subtitute for nitrogen fertiliser for dryland graminaceous crops: progress made, mechanisms of action and future potential," Symbiosis, vol. 35, pp. 209-229, 2003.

[11] G. Berg,"Plant-microbes interactions promoting plant growth and health: perfectives for controlled use of microorganisms in agriculture," App. Microbiol. Biotech., vol. 37, pp. 11-18, 2009.

[12] S. Compant, B. Reiter, A. Sessitsch, J. Norwak, C. Clement, and E. Ait-Barka, "Endophytic colonization of Vitis viniferra L. by plant growth-promoting bacterium Burkholderia sp. Strain PsJN," Appl. Environ. Microbiol., vol. 71, pp.16851693,2005 
[13] R.M. Boddey, "Biological nitrogen fixation in sugarcane: a key to energetically viable biofuel production," Crit. Rev. Plant Sci., vol. 14, pp. 263-279, 1995.

[14] L.H. Ba, "Vietnam Soil Resource," Education Publishing House, Vietnam, 2009.

[15] H.M. Tam and C.N. Diep, "Isolation, Characterization and Identification of Endophytic Bacteria in Sugarcane (Saccharum spp. L.) Cultivated on Soils of the Dong Nai province, Southeast of Vietnam," American J. Life Science, vol.2, No.2 2014, pp. 361-368. doi: 10.11648/j.ails.2014206.16.

[16] H.J. Hoben, and P. Somasegaran, "Comparison of Pour, Spread and Drop Plate Methods for Enumeration of Rhizobium spp. In Inoculants made from presterilized peat," Appl. Environ. Microbiol., vol. 44, pp. 1246-1247, 1982.

[17] M. Park, C. Kim, J. Yang, H. Lee, W. Shin, S. Kim and T. Sa, "Isolation and characterization of diazotrophic growth promoting bacteria from Gram rhizosphere of agricultural crops of Korea," Microbiological Research, vol 160, pp. 127133, 2005.

[18] C.S. Nautiyal, "An efficient microbiological growth medium for screening phosphate-solubilizing microorganisms," FEMS Microbiology Letters, vol. 170, pp.256-270, 1999.

[19] S.A. Gordon and R.P. Weber., "Colometric estimation of indolacetic acid,” Plant Physiol., vol 26, pp.192-195, 1951.

[20] J. Murphy and J. P. Riley, "A modified single solution for determination of phosphate in natural waters," Anal. Chim. Acta., vol. 27, pp. 31-36, 1962.

[21] J.M. Andersen and J.S.I. Ingram, "Tropical Soil Biology and Fertility: A Handbook on Methods, 2nd edn," CAB International Wallingford, Oxford, UK, 221, p. 1993.

[22] B. Neumann, A. Pospiech, and H.U. Schairrer, "Rapid isolation of genomic DNA from Gram-negative," Trends Gent., vol. 8, pp. 332-333, 1992.

[23] S. Turner, K.M. Pryer, V.P.M. Miao, and J.D. Palmer, "Investigating deep phylogenetic relationships among cyanobacteria and plastids by small subnit rRNA sequence analysis,” J. Eukaryotic Microbiol., vol. 46, pp. 327-338, 1999

[24] K. Tamura, D. Peterson, N. Peterson, G. Stecher, M. Nei, and S. Kumar, "MEGA5: Molecular Evolutionary Genetics Analysis using Maximum Likehood, Evolutionary Distance and Maximum Parsimony Methods," Mol. Biol. Evol., vol. 28, pp. 2731-2739, 2011.

[25] F. Poly, L.M. Joteur, R. Bally, "Improvement in RELP procedure to study the community of nitrogen fixers in soil through the diversity of nifH gene." Res. Microbiol., vol. 152, pp. 95-103, 2001.

[26] M.K. Halushka, J.B. Fan, K. Bentley, L. Hsie, N. Shen, A. Weder, R. Cooper, R. Lipshutz, and A. Charavarti, "P atterns of single-nucleotide polymorphisms in candidate genes for blood-pressure homestasis," Nat. Genet., vol. 22(3), pp. 239247, 1999.

[27] D.T.N. Thanh and C.N. Diep, "Isolation and Identification of rhizospheric bacteria in Acrisols of maize (Zea mays L.) in the eastern of South Vietnam. American J. Life Science. Vol. 2, No. 2, 2014, pp. 82-89. doi: 10.11648/j.ajls.20140202.18.
[28] G.A. Watterson, "On the number of segregation sites in general models without recobination," Theor. Pop. Biol., vol. 7, pp. 256-276, 1975.

[29] J. Rozas, and R. Rozas, "DnaSP version 4.1: an integrated program for molecular population genetics and molecular evolution analysis," Bioinformatics, vol. 15, pp. 174-175, 2005.

[30] B.R. Glick, "Plant Growth-Promoting Bacteria: Mechanisms and Applications," Hindawi Publishing Corporation, Scientifica, 2012.

[31] J.W. Kloepper, "Plant growth-promoting rhizobacteria (other systems). In: Y. Okon. (Ed.) Azospirillum/Plant Associations," CRC Press, Boca Raton, FL. USA, pp. 111-118, 1994.

[32] S. Compant, C. Clement, and A. Sessitsch, "Plant growthpromoting bacteria in the rhizo and endosphere of plants: their role, colonization, mechanisms involved and prospects for utilization," Soil Biol. Biochem., vol. 42, pp.669-678, 2010.

[33] R. Mendes, A.A. Pizziranni-Kleiner, A.L. Araujo, J.M. Raaijmakers, "Diversity of cultivated endophytic bacteria from sugarcane: genetic and biochemical characterization of Burkholderia cepacia complex isolates," Appl. Environ. Microbiol., vol. 73(22), pp. 7259-7267, 2007.

[34] G.S.Magnani, C.M. Didonet, L.M.Cruz, C.F.Picheth, F.O.Pedrosa, and E.M.,"Diversity of endophytic bacteria in Brazilian sugarcane," Genetics and Molecular Research, vol. 9(1),pp:250-258, 2010.

[35] L.A. Mirabal, E. Ortega, R. Rodes, L. Fernandez, and E. Perez, "Another nitrogen-fixing microorganisms in sugarcane stalks: bacillus brevis," Cultiv. Tropicales, vol. 21(4), pp. 9-12, 2000.

[36] R. Rivas, P. Garcia-Fraile, J.L. Zurdo-Pineiro, P.F. Mateos, E. Martinez-Molina, E.J. Bedmar, J. Sanchez-Raya, and E. Velaquez, "Saccharibacillus sacchari gen. nov. sp. nov., isolated from sugarcane,: Int. J. Syst. Evol. Microbiol., vol. 58, pp. 1850-1854, 2008

[37] M. Madhaiyan, S. Poonguzhali, J.S. Lee, K.C. Lee, and K. Hari, "Bacillus rhizosphaerae sp. nov. , a novel diazotrotrophic bacterium isolated from sugarcane rhizosphere soil," Antonie Van Leeuwenhoek, vol. 100, pp. 437-444, 2011.

[38] B.B. McSadden, "Ecology of Bacillus and Paenabacillus spp. in Agricultural Systems," Phytopathol., vol.94, pp. 1252-1258, 2004.

[39] M.R.R. Cohelo, F. Faria, N. Portilho, I. Evodio, P. Edilson, A. Soares, and L. Sedin, "Diversity of Paenabacillus spp. in the rhizosphere of four sorghum (Sorghum bicolor) cultivars sown with two contrasting levels of nitrogen fertilizer assessed by rpoB-based PCR-DGGE and sequencing analysis," J. Microbiol. Biotechnol., vol. 17(5), pp. 753-760, 2007.

[40] A. Beneduzi, D. Peres, P. Beschoren da Costa, M.H. Bodance, and L.M. Pereira, "Genetic and phenotic diversity of plantgrowth-promoting bacilli isolated from wheat fields in southern Brasil,” Res. Microbiol., vol.159, pp.244-250, 2008 a.

[41] A. Benduzi, D. Peres, L.K. Vargas, M.H. Bodanse-Zanetini, and L.M.P. Passaglia, "Evaluation of genetic diversity and plant growth promoting activities of nitrogen-fixing Bacilli isolated from rice fields in South Brasil,” Appl. Soil Ecol., vol. 39, pp.311-320, 2008b. 
[42] S. A. Eichorst, J. A. Breznak, and T.M. Schmidt, "Isolation and Characterization of Soil Bacteria That Define Terriglobus gen. nov., in the Phylum Acidobacteria," Appl. Environ. Microbiol., vol. 73(8), pp.2708-2717, 2007.

[43] D.C. White, S.D. Sutton, and D.B. Ringelberg, "The genus Sphingomonas: physiology and ecology," Current Opinion in Biotechnology, vol.7, pp.301-306, 1996.
[44] S. R. A. Ali, N. S. A. Tajuddin, S. A. Bakeri and M. B. Wahid, "Consortium of Biofertilizer Microbes," MPOB Information Series 503, Ministry of Plantation Industries and Commodities, Maylasia, June, 2010.

[45] E.W. Bumunang and O.O. Babalota, "Characterization of Rhizobacteria from field grown Genetically Modified (GM) and non-GM Maizes," Brasilian Archives of Biology and Technology, vol. 57, No. 1, pp.1-8, 2014. 